\title{
The impact of Covid-19 on the port environment: The case of Tanger Med container port, Morocco
}

\author{
Hajar Abous ${ }^{1, *}$, Mhamed Hamiche ${ }^{2}$, and Mohamed El Merouani ${ }^{3}$ \\ ${ }^{1}$ Faculty of sciences, Abdelmalek Essaâdi University-Morocco \\ ${ }^{2}$ Faculty of economic sciences FSJES ,Abdelmalek Essaâdi University -Morocco \\ ${ }^{3}$ Faculty of sciences, Abdelmalek Essaâdi University-Morocco
}

\begin{abstract}
The appearance of the COVID-19 virus has a huge impact on the economy, where many factories and logistics flows are affected. With global supply chains severely disrupted, production and consumption centers around the world are beginning to be affected by the situation. our study tried to measure the impact of this pandemic on the containers transport in Morocco, our work targeted the Tanger Med port due to its geographic position as the most important link between Africa and Europe, Autoregressive Distributed Lag (ARDL) cointegration technique was applied, this model integrates the term of lag and difference in the modeling of linear series. To verify the existence of long-term relationships, F-bond test was applied. The model was estimated on short and long term. the results were significant and has shown that the activity within Tanger Med port, experienced a shock during the pandemic period.
\end{abstract}

\section{Introduction}

Indispensable vector of globalization through which more than $80 \%$ of the flows of raw materials and goods pass, maritime transport is suffering from the pandemic due to the economic slowdown, but also to the containment measures imposed by most of the country.

At the beginning of March, the situation could seem critical. The Kearney cabinet reported that $50 \%$ of ship departures had been canceled in Chinese ports. The occupancy rate of those who sailed varied from 10 to $30 \%$, causing the disruption of supply chains in many companies. The drastic reduction in air transport and containment measures have had a significant impact on fuel supplies. Oil prices have collapsed under the double effect of falling demand and disagreements among OPEC countries over limiting production. As a result, a large number of tankers are shut down and are used as storage for production that has become overabundant.

Measures taken in some countries forced ships to undergo a 14-day quarantine before being allowed to dock. However, other ports were simply closed. Crew relief was also prohibited, placing personnel in very difficult situations. As for passenger transportation, it has been stopped in many places. In Morocco, the section devoted to passengers has been closed since the country decided to cut connections with European countries at the start of the crisis. On March 24, the International Chamber of Shipping (ICS) and the International Association of Cities and Ports (IACP), sent an open letter to the governments of the G20 countries calling for increased protection of the supply chain to enable it to carry out its mission. essential supply for populations and businesses.
The United Nations Conference on Trade and Development (UNCTAD) also called for the maintenance and protection of maritime traffic and logistics chains, including traffic to the hinterland, "whose role is vital for people in these times of global crisis". It also called for accepting crew relief, which involves some 100,000 sailors around the world, every month. In USA after a case of COVID-19 was detected at Bayport and Barbours Cut, Houston port suspended operations at the two terminals [5].

European ports have also experienced a loss of activity due to reduced traffic to China. The Port of Antwerp estimates this reduction at $20 \%$, but only $1 \%$ with the rest of the world. Rotterdam, the leading European port, estimates that traffic will decrease by $1 \%$ in 2020 , instead of planned growth of $1.5 \%$. For Hamburg, where $30 \%$ of container traffic is to China. The loss of activity this year could amount to 2\% [3] Early April, 2020, China announced that they controlled the pandemic, and particularly in Wuhan, its starting point, allowed a resumption of industrial activities, which are running at $70 \%$ of their capacities in the end of April, which suggests a gradual increase in container transport. In Morocco, the National Port Agency (ANP) has put in place a whole system to ensure the continuity of its activities in terms of reception of ships and receiving goods. The measures adopted on the basis of health guidelines and in perfect consultation with the various port stakeholders have demonstrated their relevance, the ANP specified that "the intensity of activity of the port shows an almost normal level of transit goods". [6]

Thanks to the commitment of all the partners of the National port Agency (ANP) who help to welcome ships

\footnotetext{
Corresponding author: hajar.abous@gmail.com
} 
and transit goods, the operation of the port of Casablanca was not deeply impacted by the effects of COVID -19 , especially basic necessities (cereals, sugar, livestock feed, edible oil, etc.). Thus, the volume of goods has recorded approximately 6,575,960 tones from the start of 2020 until March 21. with an increase of $3 \%$ compared to the same period in 2019. On a purely health level and in application of the recommendations of the government, the port authorities demanded a rigorous prevention plan by putting in place several measures and sanitary devices aimed at countering the spread of the virus and the protection of the port community. Similarly, for the north region, all port authority services of Tanger Med hub continued to provide their service, whether at the level of the harbor master's office, piloting, towing or mooring, for to ensure maritime stopovers and handling operations.

The operational aspect was maintained under conditions framed by health restrictions in order to contain the virus. As a result, world trade takes a hit. What about port activity, especially at the port of Tanger Med Counter to the container business, passenger transport has come to a complete halt. Port traffic has been paralyzed since Morocco decided to close the borders to international traffic at the start of the crisis. In this period of global pandemic, the choice is also made on the basis of health criteria. Tanger Med's geographic position allows it to continue operating rather in an almost stable manner. In fact, the port authority has also managed to create a climate of trust by carefully respecting all health measures such as safety and cleanliness distances. Thus, for the transshipment activity, which represents more than $70 \%$ of the overall port activity, the figures are not significantly lower in comparison with the period before the crisis. Regarding import-export, except for the five or six trains that the port received daily from the two car factories, Renault Groupe in Tangier and Peugeot Société Anonyme (PSA) in Kenitra, everything continues to function almost as before. The Ships continue their stops, the freight continues to be unloaded from the vessels, the customs and all the departments concerned work normally to support the economy of Morocco. In terms of value, the Tanger Med complex weighs $50 \%$ of all kingdom trade, the other 15 ports take care of the second half. However, it is not excluded that activity will decline in the coming weeks. "Import requirements could drop and exports too, as many factories (textiles and cars) have slowed production.

\section{The national and international economic situation}

\subsection{Impact of the international crisis}

The global economy is expected to post one of the most notable underperformances in history. The IMF's (International Monetary Fund) economic outlook for April is less than optimistic. After predicting an increase in world Gross Domestic Product (GDP) in January 2020, the Bretton Woods Institute now expects a $2.9 \%$ decline in 2020, with brutal recessions in the euro area, in Spain and Italy in particular ( $-8 \%$ and $-9.1 \%$ respectively.). For
2021, the economies of these countries are expected to rebound, recording growth rates ranging from $4.3 \%$ to $5.2 \%$. The Organization for Economic Co-operation and Development (OECD) reports annual growth loss of 2 percentage points for each month of containment and 4 to 6 percentage points over a quarter in advanced and emerging countries. These figures must be taken with caution given the uncertainty weighing on the international economic situation, the hope being to be able to find a medical solution within a short horizon, facilitating a complete resumption of activity. In emerging and developing countries, the picture is no more reassuring. The IMF expects a recession with a decline in group GDP of $1 \%$ in 2020. In 2021, this institution forecasts rapid growth at $6.6 \%$. The manufacturing sector has shown signs of slowing down even before the implementation of containment measures. This could mean a more pronounced impact for the month of April or even the months to come. The real impact is exacerbated by the flight to quality assets, a classic reaction in these moments of uncertainty. This attitude of investors is instantly manifested in the widening of spreads, an increase in interest rates backed by securities from emerging countries. At the end of the first three months of the year, net portfolio capital outflows peaked at \$87 billion, four times more than the amount recorded in the same period in 2008 . The corollary of this quest for lowerrisk assets is a significant appreciation of the dollar vis-àvis world currencies, which should weigh on the balance sheets of companies greedy in dollar assets. Mechanically, the world raw materials markets have combined all these dynamics into a free fall in prices, mainly for energy products. Thus, Brent oil prices approached the \$ 16 bar in April 2020. OPEC's agreement on April 12 to reduce production by almost $10 \%$ or 9.7 million barrels per day should temporarily support prices on world markets without radically reversing.

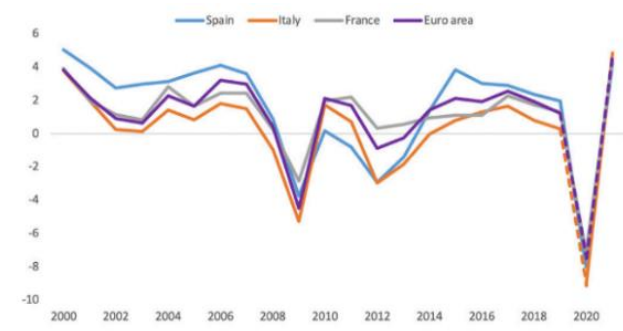

Fig. 1. Growth projection for our main trading partners, FMI World Economic Outlook April 2020.

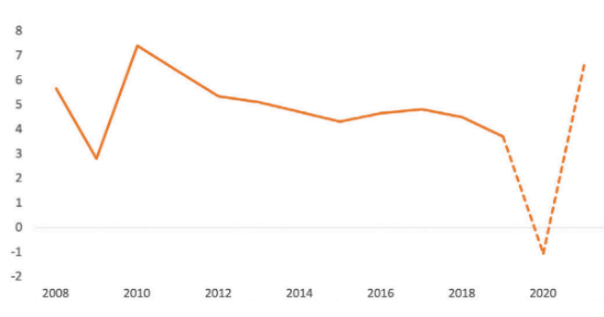

Fig. 2. Growth projection for emerging and developing countries, IMF World Economic Outlook April 2020 


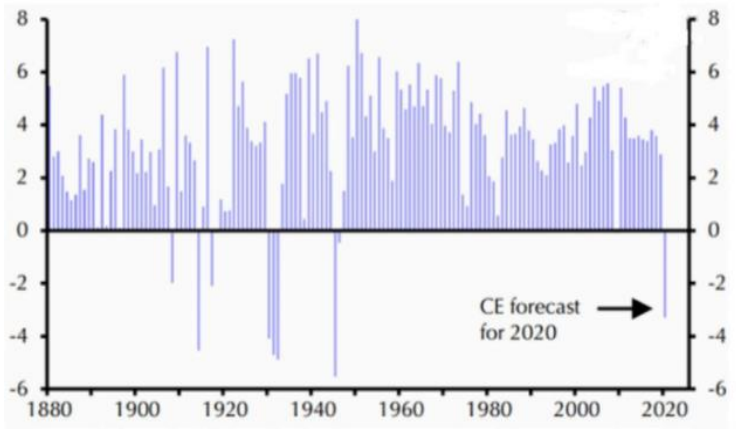

Fig. 3. Projection of global growth, Capital Economicus, 2020

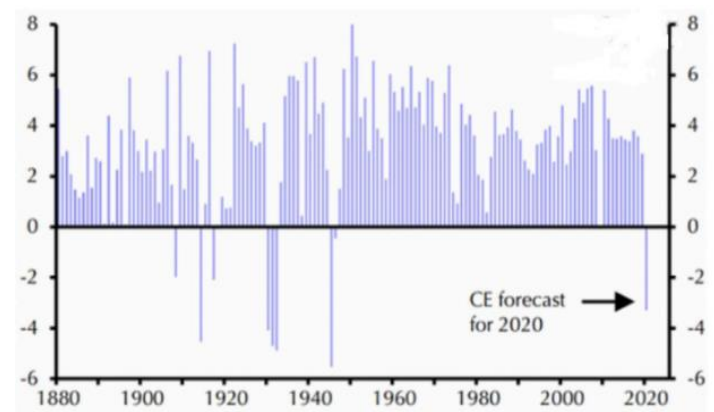

Fig. 3. Projection of global growth, Capital Economicus, 2020

Table 1. Panoply of actions taken internationally

\begin{tabular}{|c|c|c|c|}
\hline \multirow{2}{*}{$\begin{array}{c}\text { Monetary } \\
\text { Policy }\end{array}$} & \multirow{2}{*}{$\begin{array}{c}\text { Macro } \\
\text { prudential } \\
\text { policy }\end{array}$} & \multicolumn{2}{|c|}{ budgetary policy } \\
\hline & & $\begin{array}{c}\text { For the } \\
\text { benefit of } \\
\text { households }\end{array}$ & $\begin{array}{c}\begin{array}{c}\text { For the } \\
\text { benefit of } \\
\text { businesses }\end{array} \\
\end{array}$ \\
\hline $\begin{array}{l}\text { Drastic drop in } \\
\text { the key interest } \\
\text { rate. } \\
\text { Quantitative } \\
\text { easing: } \\
\text { Acquisitions } \\
\text { of treasury } \\
\text { bonds (T-bills) } \\
\text { and private } \\
\text { bonds, on an } \\
\text { unprecedented } \\
\text { scale* } \\
\text { Objective: } \\
\text { supply of } \\
\text { liquidity to } \\
\text { ease tensions } \\
\text { on rates. }\end{array}$ & $\begin{array}{l}\text { Easing of } \\
\text { prudential } \\
\text { constraints } \\
\text { on the } \\
\text { banking } \\
\text { sector: } \\
\text { - relaxation } \\
\text { of the rules } \\
\text { of } \\
\text { provisioning } \\
\text { of overdue } \\
\text { receivables } \\
\text { - softened } \\
\text { equity } \\
\text { requirements } \\
\text { - reduction of } \\
\text { the reserve } \\
\text { requirement } \\
\text { Objective: to } \\
\text { provide } \\
\text { banks with } \\
\text { liquidity to } \\
\text { encourage } \\
\text { them to } \\
\text { finance } \\
\text { businesses. }\end{array}$ & $\begin{array}{l}\cdot \text { Direct } \\
\text { transfers to } \\
\text { households } \\
\text { and wage } \\
\text { subsidies. } \\
\text { - Increase in } \\
\text { unemployment } \\
\text { benefits } \\
\text { - Reduction of } \\
\text { income tax } \\
\text { and other } \\
\text { taxes. } \\
\cdot \text { Distribution } \\
\text { of food } \\
\text { purchase } \\
\text { coupons to } \\
\text { poor } \\
\text { populations. } \\
\text { Postponement } \\
\text { of credit } \\
\text { maturities ** }\end{array}$ & $\begin{array}{l}\cdot \text { Exemption if } \\
\text { not } \\
\text { postponement } \\
\text { of tax } \\
\text { deadlines. } \\
\text { - Direct } \\
\text { transfers to the } \\
\text { benefit of } \\
\text { affected } \\
\text { companies } \\
\text { (especially } \\
\text { SMEs) } \\
\text { - Encourage } \\
\text { the reduction } \\
\text { of working } \\
\text { hours, instead } \\
\text { of dismissal } \\
\text { - } \\
\text { Postponement } \\
\text { of credit } \\
\text { maturities and } \\
\text { provision of } \\
\text { guarantees and } \\
\text { lines of credit. }\end{array}$ \\
\hline
\end{tabular}

Source: [1]

\subsection{Initial impact of the crisis in Morocco}

In its conjuncture note, published on April 8, 2020, the High Commission for Planning (HCP) presents the evolution of the Moroccan economy in Q1 2020 and the outlook for Q2 2020 in the context of the COVID-19 shock. In the first quarter, there is talk of a possible slowdown in growth in the secondary sector, which would have grown by $0.5 \%$ against the $1.6 \%$ initially forecast. Also, the external demand addressed to Morocco would have decreased by $3.5 \%$. Exports would have dropped $22.8 \%$ in the first quarter while imports would have dropped $4.8 \%$ (HCP).

Regarding domestic demand, taking into account the containment measures taken by the authorities, the HCP would observe a deceleration in the rate of growth of household consumption which would stand at $1.2 \%$ year on year. On the other hand, public consumption would have grown by $3.2 \%$, compared to the first quarter of 2020 , consolidating the authorities' efforts to respond to the crisis. These developments are leading the Kingdom's statistical institute to review its growth figures. Thus, the Moroccan economy would have grown by $1.1 \%$ in Q1 2020 and should contract by $-1.8 \%$ in Q2 2020, against $1.8 \%$ and $2.1 \%$ initially forecast.

As for Bank Al Maghrib, the latest figures presented at the end of its council of March 17, 2020 show a GDP growth of $2.3 \%$ for 2020 . This forecast, not taking into account the progression of the pandemic in Morocco, will undoubtedly be revised downwards. On the side of international institutions, the World Bank in its Baseline scenario forecasts a decline in GDP of $1.5 \%$ in 2020 . The International Monetary Fund expects a decline in GDP of $3.7 \%$ for the year 2020 and a recovery of $4.8 \%$ in 2021 . Regarding external accounts, the projection of the current account shows a worsening of the current deficit which would amount to $7.8 \%$ of GDP in 2020 to return to $4.3 \%$ in 2021 (World Bank).

Such a development would have important implications for the parity of the dirham which, a priori, under the effect of uncertainty, should depreciate as the currencies constituting the reference basket appreciate. The deterioration of the budgetary balance would worsen the situation of twin deficits in 2020.

For emerging and developing countries, the IMF recommends the use of automatic stabilizers when they exist and calls for multilateral cooperation to help countries with limited fiscal space. In this sense, the measures adopted by Morocco are in line with these recommendations and will make it possible to minimize as much as possible the impact of the covid-19 shock on the Moroccan economy.

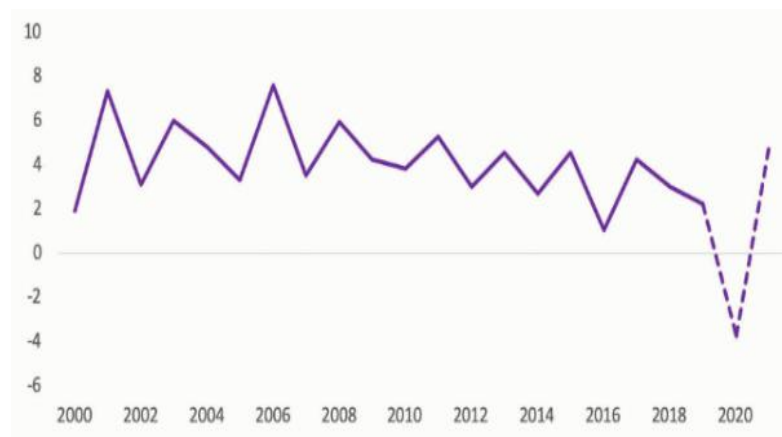

Fig. 5. Morocco's GDP growth projection, IMF World Economic Outlook April 2020 


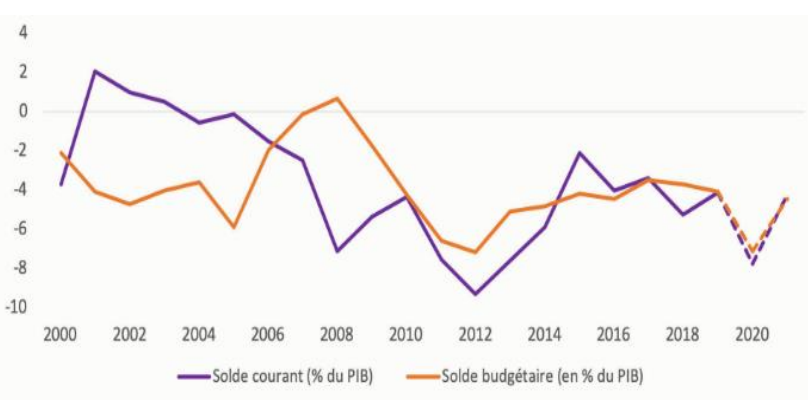

Fig. 6. Projections of the current account and the budgetary balance, IMF World Economic Outlook April 2020

\subsection{Spread of COVID-19}

The spread of the COVID- 19 pandemic was felt in Morocco from the beginning of March. From March 2 to 13 , the cases of coronavirus recorded were limited to people from outside (Italy, France, Spain and Austria). On March 14, ten new cases were reported (18 cases in total), including eight Moroccans from Europe. The ninth case concerns the first local contamination from a recorded case, and the 18th is the Minister of Equipment, Transport, Logistics and Water, Mr. Abdelkader Amara. As of March 15, the number of cases increases more rapidly (Figure 7). Morocco therefore revealed on Saturday March 14 the suspension of air links with Italy, Spain, Algeria, France, Portugal, Germany, Belgium and the Netherlands before completely shutting down the borders vis-à-vis foreign passengers. On March 11, Morocco recorded the first death, nearly $17 \%$ of the total number of people infected. The first case was cured on March 13, representing $13 \%$ of the number of people infected with COVID-19, (Figure 7).

After twenty days of evolution, the rates of recovery and death are almost identical. With the exception of China, the corona virus has spread worldwide through the movement of people from one country to another and through physical contact. which explains the closure of the borders and the cancellation of air and maritime transport. Since the appearance of the first cases, Morocco has taken very early measures to control the situation, Morocco has implemented measures to limit the spread of the epidemic. Flights to several countries are suspended. On March 19, the declaration of a state of health emergency by imposing confinement on the population. In this regard, the movements of individuals must be justified by an authorization issued by the competent authorities.

\section{Data and methodology}

\subsection{The data}

COVID-19 data are extracted from daily situation reports published by WHO from 3/21/2020. Consequently, our sample covers the period from $3 / 21 / 2020$ to $4 / 30 / 2020$ (42 observations). Data on the quantities of goods transshipped in 20- and 40-foot containers at the Tanger
Med port. The unit of measurement used is "twenty-foot equivalent (TEU).
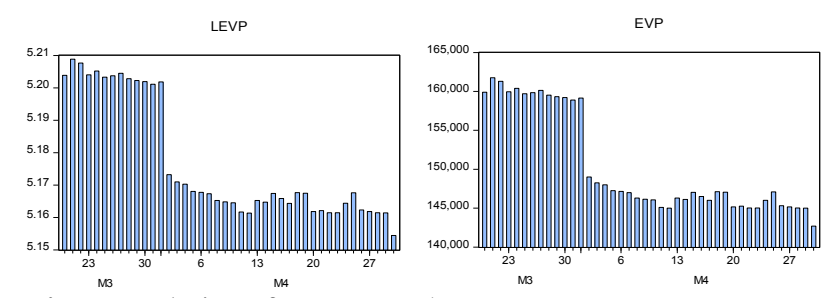

Fig. 7. Evolution of Tanger Med port TEUs
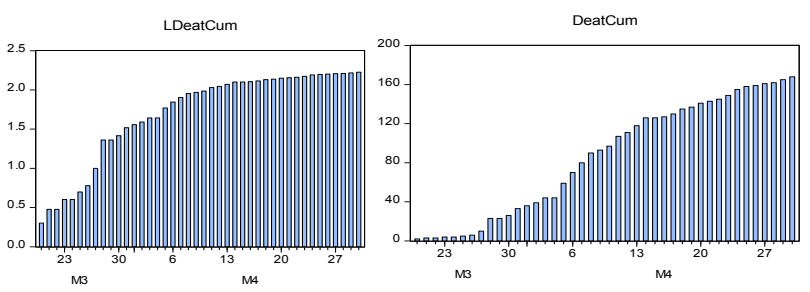

Fig. 8. Cumulative evolution of new COVID-19 cases
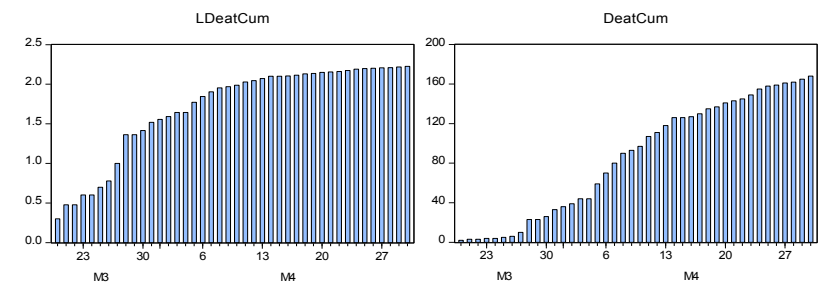

Fig. 9. Cumulative evolution of deaths caused by COVID-19

Figure 7 shows that the number of TEUs shows a continuous decrease since the start of confinement, and a crash from April 2, 2020, at the same time Figure 8 and 9 shows that the number of infected people exceeds 1000 cases, too that deaths exceed 40 cases. At that time the death rate of COVID-19 began to worry the population. Table 2 presents the descriptive statistics of the logarithms of the series selected.

Table 2. Summary statistics

\begin{tabular}{cccc}
\hline & LCASCUM & LDEATCUM & LEVP \\
\hline Mean & 2.996731 & 1.699453 & 5.176883 \\
Median & 3.121748 & 1.977627 & 5.167435 \\
Max & 3.635584 & 2.225309 & 5.208844 \\
Min & 1.799341 & 0.301030 & 5.154424 \\
Std. Dev. & 0.533178 & 0.592896 & 0.018630 \\
Skewness & -0.690472 & -1.104933 & 0.746832 \\
Kurtosis & 2.392779 & 2.845745 & 1.709869 \\
\hline Observations & 42 & 42 & 42 \\
\hline
\end{tabular}

The Augmented Dickey-Fuller (ADF) unit root test shows that the series are of order I (1) or I (0).

Table 3. Unit root test

\begin{tabular}{cccc}
\hline & Level & $\begin{array}{l}\text { First } \\
\text { difference }\end{array}$ & $\begin{array}{l}\text { Ordre } \\
\text { d'intégration }\end{array}$ \\
\hline LCASCUM & $-6.743378 *$ & -- & I $(0)$. \\
LDEATCUM & $-3.761478 *$ & -- & I $(0)$. \\
LEVP & -1.049885 & $-6.400903 *$ & I $(1)$. \\
\hline Notes: $($ i) $* * * * *$ and $*$ means significance at $1 \%, 5 \%$ and $10 \% ;$
\end{tabular}
(ii) the optimal lag selection is based on AIC information criterion; (iii) 


\subsection{Methodology of approach}

In order to estimate the relationship between the number of TEUs, the cumulative number of new COVID-19 cases and the cumulative number of COVID-19 cases of death, we use the Auto Regressive Distributed Lag model (ARDL) proposed by [4] compatible with the series of integration orders I (0) and I (1).

The framework of [4] uses a linear transformation to integrate the short-term adjustments into the long-term equilibrium, using an Error Correction Model (ECM), as follows:

$$
\begin{aligned}
\Delta L E V P_{t}=c+\delta_{\text {LEVP }} \text { LEVP }_{t-1}+\delta_{\text {LCASCUM LCASCUM }_{t-1}} & \\
& +\delta_{\text {LDEATCUM }_{P} \text { LEATCUM }_{t-1}} \\
& +\sum_{I+1}^{P} \alpha_{i} \Delta L E V P_{t-i}+\sum_{I+1}^{P} \beta_{i} \Delta \text { LCASCUM }_{t-i} \\
& +\sum_{I+1}^{P} \gamma_{i} \Delta \text { LDEATCUM }_{t-i}+\theta E C T_{t-1}+\varepsilon_{t}
\end{aligned}
$$

where $(i) c$ and $\varepsilon$ are respectively the intercept and the error term, (ii) the short term terms are designated by $\Delta$, while long term terms are indicated by the term $\delta$, (iii) is the maximum number of delays (four in our case), (iv) the error correction term is noted ECT ( $\theta$ must be negative and significant in order to validate the long-term relationship). The optimal number of delays is selected according to the Akaike information criteria (AIC). The existence of a long-term relationship is validated using $\mathrm{F}$ statistic, where the null hypothesis of non-cointegration is $\delta L E V P=\delta L C A S C U M=\delta L D E A T C U M=0$.

We perform a series of post-estimation tests to verify the residual correlation series (Breusch-Godfrey LM test) and presence of ARCH effects (Engle ARCH-LM test).

\section{Results and discussion}

In the first step, we verify the existence of a long-term relationship, by applying the linked tests which assume a lower bound for the series I (0) and an upper bound for the series I (1), the critical values being derived from [2]. F-statistic indicates a cointegration relationship if the values are greater than the critical value of the upper limit. For our model, we note the existence of a long-term relationship between TEUs, the number of new coronavirus cases, and the cases of death (Table 4).

Table 4. Bounds test results

\begin{tabular}{ccc|c}
\hline & F-statistic & Critical values & \multirow{2}{*}{ Conclusion } \\
$\begin{array}{c}\text { Model } \\
\text { specification }\end{array}$ & $\begin{array}{c}\text { Lower } \\
\text { bound } \\
(\mathbf{I}(\mathbf{0}))\end{array}$ & $\begin{array}{c}\text { Upper } \\
\text { bound } \\
(\mathbf{I}(\mathbf{1}))\end{array}$ & \\
\hline 4.270049 & 3.17 & 4.14 & cointegration \\
\hline
\end{tabular}

Notes: (i) Critical values at $10 \%$ significance level

In the second step, we estimate the ARDL model (Table 5). For the model results, a long-term negative connection between TEUs, the number of new cases of coronavirus and the cases of death are observed. The negative effect is stronger for the 3 lagged variable:

$(\operatorname{LCASCUM}(-3)=-0.153533)$.

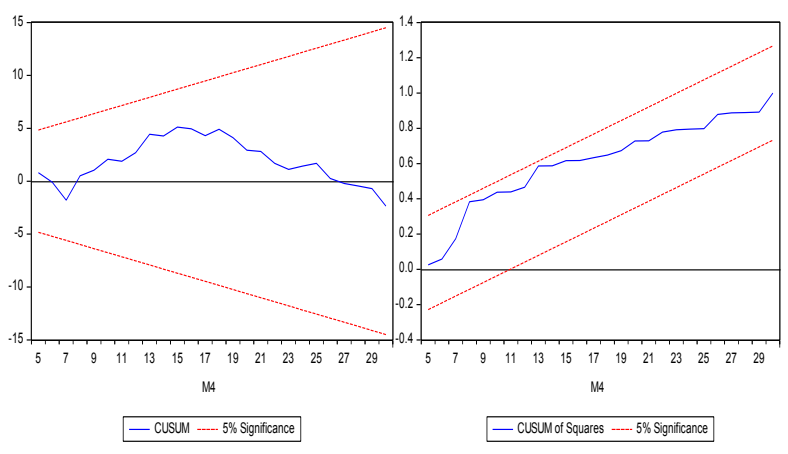

Fig. 10. Critical bonds test

Both CUSUM and CUSUM OF Squares shows that our model is withing the $5 \%$ significant value.

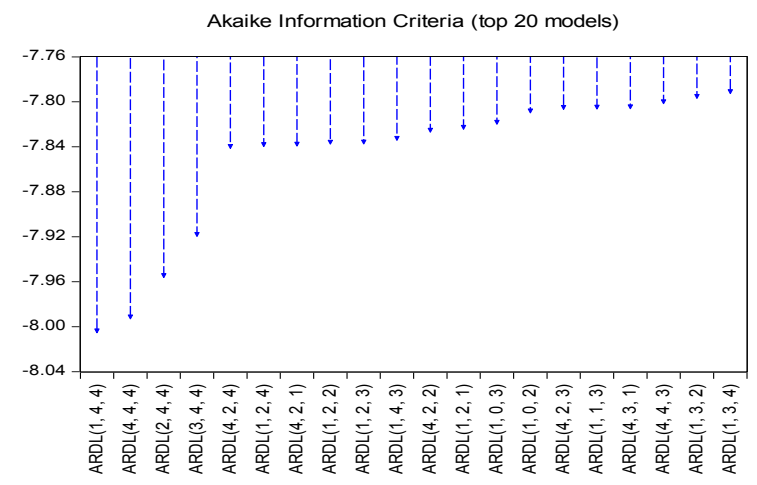

Fig. 11. Optimal lag selection for ARDL model using Akaike Information Criteria

The Akaike Information Criteria shows that the optimal number of lags for our model is $\operatorname{ARDL}(1,3,4)$. The optimal number for lags is selected by choosing the model with the lowest Akaike Information Criteria value.

Table 5. Estimation of the ARDL

\begin{tabular}{lll}
\hline Variable & Coefficient & t-Statistic \\
\hline LEVP (-1) & $0.534762^{* * *}$ & 4.000050 \\
LDEATCUM & $-0.027333^{*}$ & -1.846299 \\
LDEATCUM (-1) & $0.046222^{* *}$ & 2.015266 \\
LDEATCUM (-2) & $-0.033903^{*}$ & -1.424771 \\
LDEATCUM (-3) & $0.038791^{*}$ & 1.751924 \\
LDEATCUM (-4) & $-0.043735^{* * *}$ & -2.810770 \\
LCASCUM & 0.063123 & 1.523279 \\
LCASCUM (-1) & -0.010269 & -0.187177 \\
LCASCUM (-2) & 0.020653 & 0.395596 \\
LCASCUM (-3) & $-0.153533^{* * *}$ & -3.114376 \\
LCASCUM (-4) & $0.094142^{* * *}$ & 2.553956 \\
C & $2.393269^{* * *}$ & 3.470761 \\
\hline Serial correlation & \multicolumn{2}{c}{ NO } \\
ARCH effects & \multicolumn{2}{c}{ NO } \\
Stability & \multicolumn{2}{c}{ YES } \\
\hline
\end{tabular}

Notes: (i) ***, ** and * means significance at $1 \%, 5 \%$ and $10 \%$; (ii) standard deviations are in square brackets;(iii) BreuschGodfrey LM test for serial correlation is used; (iv) ARCH effects for conditional heteroscedasticity (with 4 lags); (v) Ramsey and CUSUM tests are used to check the stability. 
Table 6. Estimated Short-run Error Correction Model (ECMARDL)

\begin{tabular}{|c|c|c|c|c|}
\hline \multicolumn{2}{|l|}{ Variable } & Coefficient & t-Statistic & Prob. \\
\hline \multicolumn{2}{|l|}{$\mathbf{C}$} & $2.393269 * * *$ & 3.715579 & 0.0010 \\
\hline \multicolumn{2}{|c|}{ D (LCASCUM) } & $0.063123 * *$ & 2.042886 & 0.0513 \\
\hline \multicolumn{2}{|c|}{$D(\operatorname{LCASCUM}(-1))$} & 0.038738 & 1.152331 & 0.2597 \\
\hline \multicolumn{2}{|c|}{ D (LCASCUM (-2)) } & 0.059391 & 1.507206 & 0.1438 \\
\hline \multicolumn{2}{|c|}{ D (LCASCUM (-3)) } & $-0.094142 * * *$ & -3.142253 & 0.0042 \\
\hline \multicolumn{2}{|c|}{ D (LDEATCUM) } & $-0.027333 *$ & -1.965354 & 0.0601 \\
\hline \multicolumn{2}{|c|}{ D (LDEATCUM (-1)) } & $0.038846 * * *$ & 2.622091 & 0.0144 \\
\hline \multicolumn{2}{|c|}{ D (LDEATCUM (-2)) } & 0.004944 & 0.344947 & 0.7329 \\
\hline \multicolumn{2}{|c|}{ D (LDEATCUM (-3)) } & $0.043735 * *$ & 3.036745 & 0.0054 \\
\hline \multicolumn{2}{|c|}{ CointEq $(-1) *$} & $-0.465238^{* * *}$ & -3.714235 & 0.0010 \\
\hline Tests & Value & Signif. & I (0) & I (1) \\
\hline F-Bound Test & 4.2700 & $10 \%$ & 3.17 & 4.14 \\
\hline t-Bound Test & -3.7142 & $10 \%$ & -2.57 & -3.21 \\
\hline \multicolumn{3}{|c|}{$\begin{array}{l}\text { Serial correlation } \\
\end{array}$} & \multicolumn{2}{|l|}{$\mathrm{NO}$} \\
\hline \multicolumn{3}{|c|}{ ARCH effects } & \multicolumn{2}{|l|}{ NO } \\
\hline \multicolumn{3}{|c|}{ Stability } & \multicolumn{2}{|l|}{ YES } \\
\hline
\end{tabular}

Notes: (i) ***,** and * means significance at $1 \%, 5 \%$ and $10 \%$; (ii) standard deviations are in square brackets;(iii) Breusch-Godfrey LM test for serial correlation is used; (iv) ARCH effects for conditional heteroscedasticity (with 4 lags); (v) Ramsey and CUSUM tests are used to check the stability.

The same results are confirmed by the short-term model (ECM-ARDL) the variable LCASCUM (-3) continues to have the most significant impact in the model with a coefficient negatively significant at $1 \%$.

\section{Conclusions}

The coronavirus crisis has generated notable shock waves across all sectors of the economy. Maritime transport was also affected by this health crisis but to a lesser degree than the other sectors of activity. In this context, the objective of our article was to see how the COVID-19 figures influenced the quantities of goods measured in TEUs within the Tanger Med seaport. All of the model's stability and validity tests were significant.

Our ARDL estimate showed a negative and significant impact of the coronavirus crisis on container transport operations within the port that is the subject of our study. For the moment, activity remains generally almost normal, but the downside risk persists. In fact, according to statistics from the Federation of National Associations of Charter Brokers and Maritime Agents (FONASBA, there were not yet serious disturbances), at the end of March 2020, the port activity of container transshipment recorded a slight decrease of $1.2 \%$, representing a total traffic of 4.8 million tones. This almost maintained activity level was mainly driven by the good orientation of containerized trade, which reached around 194,000 TEU, however, traffic overall, the port recorded a slight increase in solid bulk import traffic, recording a $12 \%$ increase in volume (ANP). Imports of new vehicles generated traffic of 12,736 units, an increase of $3 \%$.

All of these flows increased by $2.5 \%$, which were carried on board 230 ships. Why reason has this overall port traffic not been subject to major disruptions? Indeed, the epidemic started in China at the end of December. However, for a Chinese delivery to arrive at the port of Tanger Med, the order must be placed 4 to 5 months in advance. Consequently, the impact of the crisis can only be felt on Moroccan foreign trade after a few weeks or even a few months, if this is true for trade relations with China, the situation is different for trade with the Europe which is close to the Tangier Med port. The impact on Europe will accelerate given the current situation.

Italy, for example, which is an important supplier to Morocco, is completely confined. It cannot produce and cannot deliver. Inevitably this will have an impact in the coming weeks. In general, with all the confinements that are decided, travel bans, restrictions, health, inevitably, there will be fewer commercial transactions, less business, therefore inevitably there will be a negative impact on Moroccan businesses and on Employment. Note that CFG bank projections predict a monthly decrease of 2.6 million tones in Morocco's foreign trade from this March, due to the effects of the coronavirus pandemic.

\section{Acknowledgment}

This paper and the research behind it would not have been possible without the exceptional support of my supervisor, I also acknowledge the APM Terminal Company for their help and for providing us with the database used in our empirical study.

\section{References}

1. ALI, Abdelaaziz Ait, BASSOU, Abdelhak, DRYEF, M.'hammed, et al. LA STRATÉGIE DU MAROC FACE AU COVID-19. 2020. Available on : https://www.policycenter.ma/sites/default/files/PP20-07_LastrategieduMarocFaceAuCovid19.pdf

2. Narayan, Paresh Kumar. "The saving and investment nexus for China: evidence from cointegration tests." Applied economics 37.17 (2005): 1979-1990.

3. Patrick Hébrard, L'impact du Covid-19 sur le monde maritime. Fondation pour la recherche stratégique, (2020). Available https://www.frstrategie.org/publications/notes/impac t-covid-19-sur-monde-maritime-2020

4. Pesaran, M. Hashem, Yongcheol Shin, and Richard J. Smith. "Bounds testing approaches to the analysis of level relationships." Journal of applied econometrics 16.3 (2001): 289-326.

5. SCHULER, M. Operations Suspended at Port Houston Container Terminals After Worker Tests Positive for COVID-19, (2020). Available: https://gcaptain.com/port-of-houston-containerterminals-suspend-operations-after-worker-testspositive-for-covid-19/.

6. Yahia Hatim, Casablanca Port Imports Continue Regularly Despite COVID-19 Crisis, (2020). Available:

https://www.moroccoworldnews.com/2020/03/2973 01/casablanca-port-imports-continue-regularlydespite-covid-19-crisis/ 